\title{
The effectiveness of semantic therapy training on psychological resilience and psychological well-being of mourning women
}

\section{Rasoul Chamani Ghalandari ${ }^{1}$, Farideh Dokaneifard $^{2}$, Roonak Rezaei $^{3}$}

1- Master of Science in Counseling and Guidance, Army Air Force Health Administration, Tehran, Iran (Corresponding Author). ORCID: 0000-0001-7906-4557_ E-mail: rasoul_chamani@yahoo.com 2- Assistant Professor, Consulting group, Islamic Azad University of Roudhan, Roudhan, Iran. ORCID: 00000001-8301-7155

3- Master of Clinical Psychology, Kurdistan University of Medical Sciences, Sanandaj, Iran. ORCID: 00000001-6588-7894

\begin{abstract}
Introduction: The loss of one of the family members is causing a disturbance in the balance of the people, and meaning in life is combined with well-being and has an effective role in their ability to cope positively with psychological stresses.
\end{abstract}

Aim: The present study was to determine the effectiveness of Logotherapy training on resilience and psychological well-being of women with mourning experience.

Method: The present study was quasi-experimental and pretest-posttest with control group. The statistical population of this study was women with mourning experience referring to police counseling centers in Tehran in the spring of 1398. 30 subjects were selected using the sampling method and were divided into two groups of 15 subjects. The instruments for collecting the Conner and Davidson resiliency questionnaires and the psychological wellbeing of the Ryff are. The experimental group in the Logotherapy training sessions for 10 sessions of 90 minutes. For data analysis, covariance analysis was used.

Results: Logotherapy training led to increased resilience and psychological well-being of the experimental group compared to the control group.

Conclusion: Therapists can use Logotherapy as an effective way to improve the resilience and the psychological well-being of people with mournful experience.

Keywords: Logotherapy, Psychological well-being, Resilience 


\title{
اثربخشى آموزش معنا درمانى بر تاب آورى و بهزيستى روانشناختى زنان داراى تجربه سوى
}

\author{
رسول جمنى قلندرى'، فريده د كانه اى فرد'، روناك رضائى \\ ا. كارشناس ارشد مشاوره و راهنمايى، اداره بهداشت و درمان نيروى هوايى ارتش، تهران، ايران (مولف مسئول). \\ rasoul_chamani@yahoo.com: \\ r. استاديار، كروه مشاوره، دانشكاه آزاد اسلامى رودهن، رودهن، ايران.

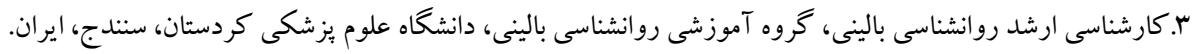

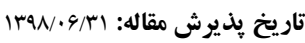 \\ تاريخ دريافت مقاله: ه.ب//
}

جكيده

مقدمه: از دست دادن يكى از اعضاى خانو اده موجب برهم خوردن تعادل افر اد مىشود و معنا در زندگى با بهزيستى در آميخته و

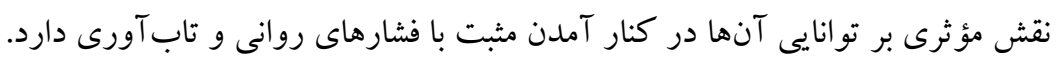
هدف: هدف برزوهش حاضر تعيين اثربخشى آموزش معنا درمانى بر تابآورى و بهزيستى روانشناختى زنان داراى تجربه سوگك

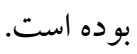

روش: يُزوهش حاضر از نوع شبه آزمايشى و طرح ييش آزمون - يس آزمون با گروه گُواه بود. جامعه آمارى اين يُزوهش زنان

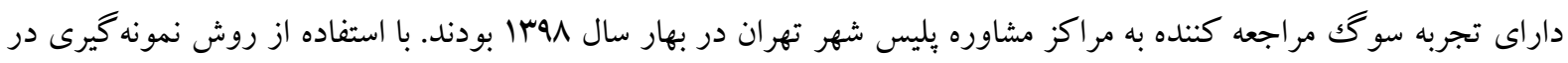

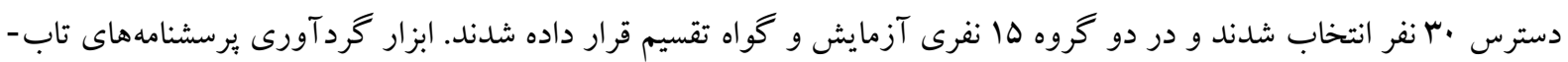

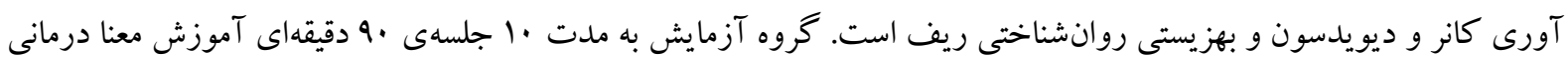
شر كت داده شدند. براى تحليل دادهها از آزمون تحليل كوواريانس استفاده شد. رون.

يافتهها: آموزش معنا درمانى منجر به افزايش تاب آورى و بهزيستى روانشناختى گروه آزمايش در مقايسه با گروه كنترل شد. نتيجه كيرى: درمانكران مى تواند از معنا درمانى به عنوان راهكارى مؤثر براى بهبود تاب آورى و بهزيستى روانى افراد داراى تجربه سو گك استفاده كنند. كليدوازهها: معنا درمانى، تاب آورى، بهزيستى روانشناختى 
جذيرى انطباقى، افراد داراى سطح بالاى تابَآورى با

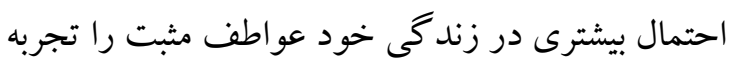
مىنمايند و اعتماد به نفس بالاترى داشته و در مقايسه با افرادى كه از سطح بِيين تابآورى برخوردارند،

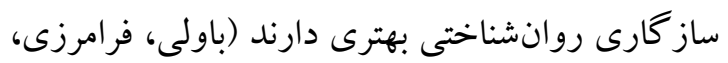
منشايى و خالديان، سا.Y). بسيارى از محققان بين تابآورى و مشكلات روانشناختى رابطهاى معنادار و

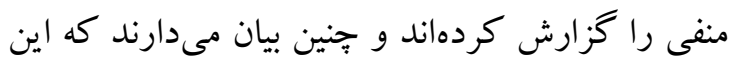
سازه مى تو اند به عنوان عامل ميانجى بين سلامتروان و بسيارى ديخر از متغيرها قرار گيرد و با ارتقاى تابآورى، فرد مىتواند در برابر عوامل استرس زا، اضطرابآور و همجنين عواملى كه مسبب به وجود ورد آمدن بسيارى از مشكلات روانشناختى آنها مىشود از خود مقاومت نشان داده و بر آنها غلبه نمايند (اهرعاشقى، عqrاן). تابآورى از بروز مشكلات روانشناختى جلو گيرى كرده و افراد را از اثرات روانشناختى حوادث آسيبزا حفظ مى كند. شواهد يزوهشى نشان مىدهد كه تاب آورى مى تواند سلامت

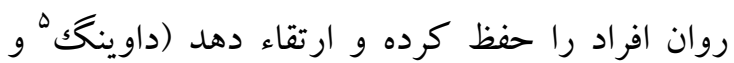

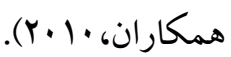
از طرف ديخر، بهزيستى روانشناختى مستلزم دركى جالشهاى وجودى زندگى است. رويكرد بهزيستى روانشناختى رشد و تحول مشاهده شده در برابر جالشهاى وجودى زندگى را بررسى مى كند و به شدت بر توسعه انسانى تأكيد دارد بهعنوان مثال دنبال نمودن اهداف معنادار، تحول و بيشرفت به عنوان يكك

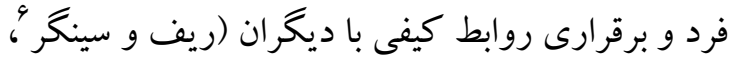

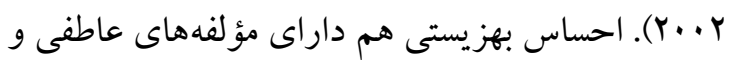
هم مؤلفههاى شناختى است. افراد با احساس بهزيستى بالا به طور عمدهاى هيجانات مثبت را تجربه مى كنند و

5 . Downing

6. Ryff \& Singer

\section{مقدمه} سو گك حالت غم و اندوه و ناراحتى شديد درونى در واكنش به از دست دادن شخص يا عقيده و فكرى خاص است. عدهاى سوگت را شامل دو بعد درونى

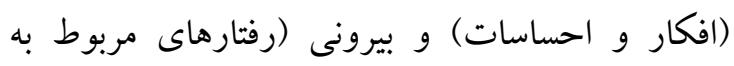

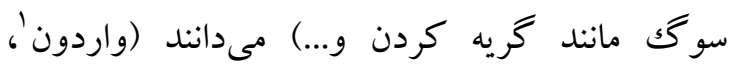

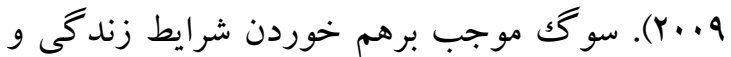
بروز علائم زيادى در افراد مىشود (روزنر، فوه و

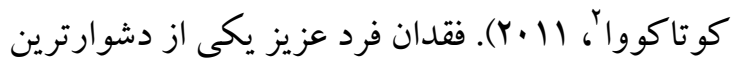
رويدادى است كه فرد مى تواند تجربه كند و اين بديده مىتواند با بيامدهاى منفى متعددى در زمينهاى

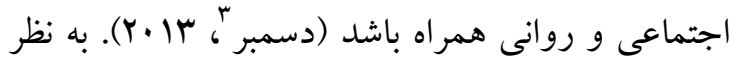

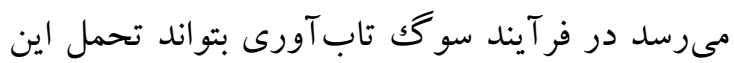
فقدان را براى افراد تسهيل بكند. تاب آورى نوعى توانايى فطرى براى رشد است كه در

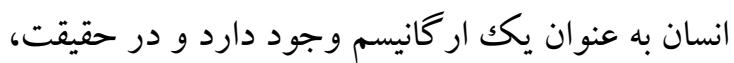
تاب آورى نوعى مكانيسم سازش مثبت را ايجاد مى كند كه جندين عامل فردى و اجتماعى را تحت عنوان عوامل محافظتى در تقويت فرد و كاهش عوامل خطر آفرين بكار مى گيرد (يامكاجى، كيواتا، شيواتأ،

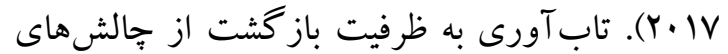
اجتماعى، مالى و يا احساسى به تعادل مجدد اطلاق

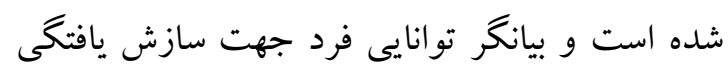
مجدد فرد در برابر غم، ضربه، شرايط نامطلوب و

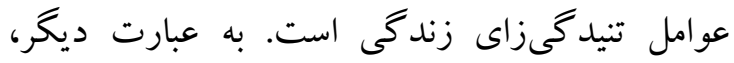

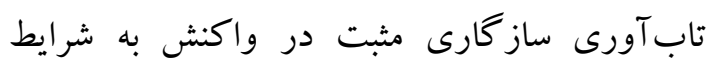

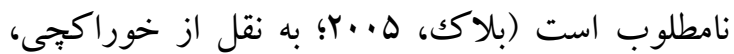
( ) I I I ). تاب آورى توانايى منطبق ساختن سطح كنترل بر حسب شرايط محيطى است. در نتيجه اين انعطاف-

\footnotetext{
. Vardon

. Rosner, Pfoh \& Kotoucova

3. December

4. Yamaguchi, Kawata, Shibata
} 
جنين تنخُنايى كه فرد در آن گرفتار شده است، باعث

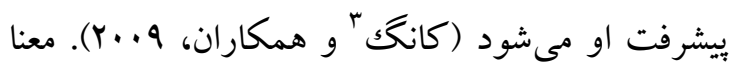
درمانى به عنوان يك كشيش طبى، عالى ترين صورت

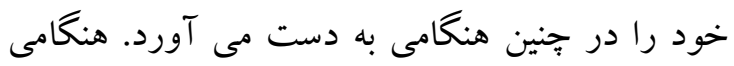
كه مى بذيريم انسان مسئول است، مجبوريم لحظه ایى له

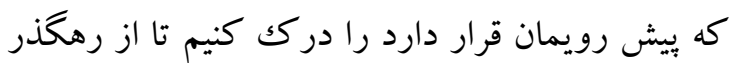
از فرصت هاى بيش رو حداكثر استفاده را بنماييم. در اين حالت يتانسيل هاى خود را محقق مى كنيم. ارزشها را جه به صورت خلاق و تجربى يا جه به صورت نكرشى در كك كرده و معنا را محقق مى نماييم (محمديوريزدى، هNץ|). در نظريه معنا درمانى انسان براى داشتن سلامت روان بايد در بى يافتن معنايى در زندكى خود باشد. در اين مكتب صحبت از آزادى روح انسان است (در گاهى، هوسا). اين مكتب بر اين باور است كه انسان تحت نيروى جبرى و محيطى و روانى قرار ندارد. انسان حق انتخاب دارد و در برابر موقعيت هايى كه قرار مى گيرد، آزادى تصميم گيرى دارد و در برابر تصميمهاى خود مسئول است. انسان معمار سرنوشت خود است و هيج قانون جبرى خاصى وجود ندارد كه او را دربند كشد. به همين جهت وظيفه اصلى معنا درمانى اين است كه به بيمار كمكك كند تا با توسل به انديشه و ذخاير ينهانى خود معناى وجودى

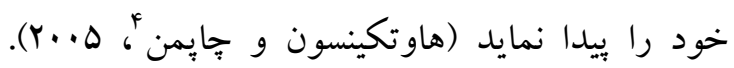
معنادارى زندگى، امرى روانى است و وابستخى تمام

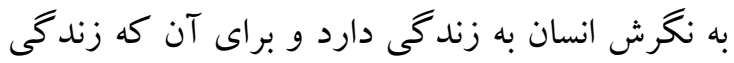
فرد معنادار شود، وى بايد معناى زندگى را دركى نمايد، تفسير درست هستى و انسان، زندگى را معنادار

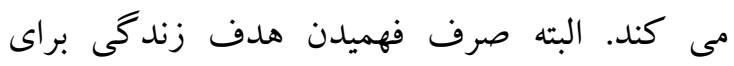
معنادار شدن آن كافى نيست بلكه بايد بخش هاى
از حوادث و وقايع بيرامون خود ارزيابى مثبى دارند، در حالى كه افراد با احساس بهزيستى بايين حوادث و و موقعيت زندگى شان را نامطلوب ارزيابى مى كنند و بيشتر هيجانات منفى نظير اضطراب، افسردگى و خشم رونى

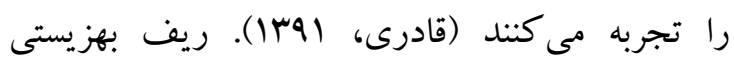
روانشناختى را اتلاش براى كمال در جهت تحقق توانايىهاى بالقوه واقعى فرد) مىداند. در اين ديدكاه بهزيستى روانشناختى در تلاش براى ارتقاء استعدادها

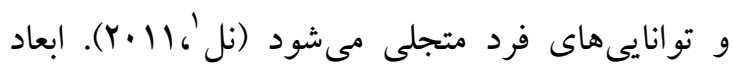
بهزيستى روانشناختى شامل يذيرش خود (توانايى ديدن و بذيرفتن نقاط قوت و ضعف خود)، رابطه مثبت

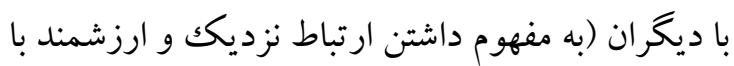
افراد مهم زندگى)، خود مختارى (توانايى و قدرت بيخيرى خواسته ها و عمل بر اساس اصول شخصى حتى اكر مخالف آداب و رسوم و تقاضاهاى اجتماعى لهو باشد)، زندكى هدفمند (به معناى داشتن غايتها و و اهدافى است كه به زندگى فرد جهت و معنا بخشد)، رشد شخصى (به اين معنا كه استعدادها و توانايىهاى

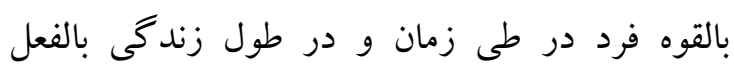
خو اهد شد) و تسلط بر محيط (توانايى تنظيم و مديريت امور زندگى به ويزه مسائل زندگى روزمره) است

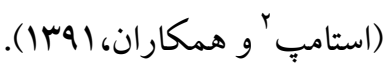

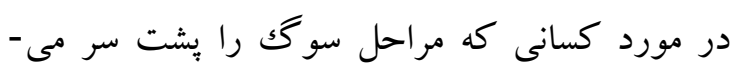
كذرانند و اوضاع روحى- روانى آنها بحرانى است،

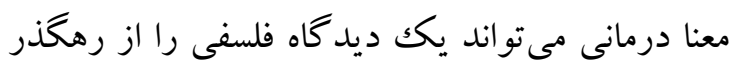

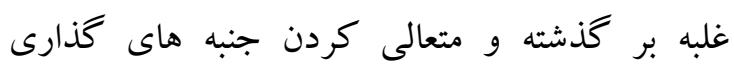
زندگى ايجاد نمايد. معنا درمانى به فرد كمكك مى كند تا در جنين شرايطى كه سرنوشت غيرقابل تغيير است، به شكل يُانه يتانسيل انسانى خود را متبلور سازد و و ترازدى را به يكك بيروزى شخصى تبديل كند و در 
سبرى نشود تبديل به اختلال سو گك مىشود و از سوى

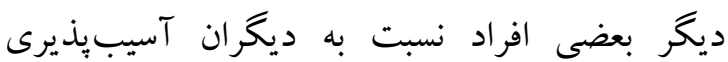
بيشترى دارند؛ ضربه روحى بر قشر زنان به خاطر طبيعت فطرى زياد است. اين افراد در برابر مشكلات نياز به كمكك و به يك سرى مهارتهايى كه بتوان آنها را در برابر اين مشكلات ايمن سازد، نياز دارند. از اينرو اين بثوهش بر آن است كه اثربخشى آموزش

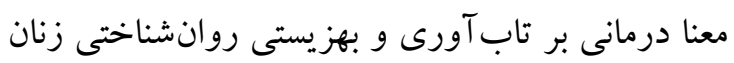
داراى تجربه سوگك شهر تهران را مورد بررسى قرار

طرح يثزوهش و شر كت كنند كان: روش يزٔوهش حاضر نيمه آزمايشى با طرح بيش آزمون، بِ بس آزمون با گروه

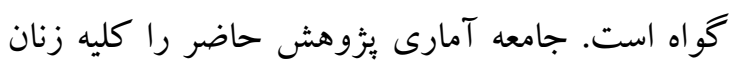
سو گك ديده ناشى از تصادفات شهر تهران در بهار سال

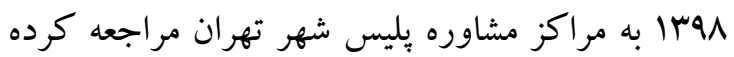

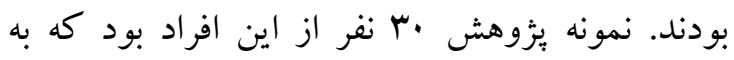

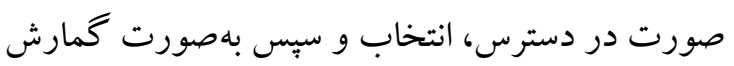
تصادفى در دو گروه آزمايش و گوراه (هانفر) جايگزين شدند. براى گروه آزمايش معنا درمانى به مدت ·ل جلسهى ·9 دقيقهاى و بهصورت گروهى اجرا شد و فاصله زمانى جلسات يككبار در هفته بود. گروه كواه هيج مداخلهاى را دريافت نكردند. يـس از

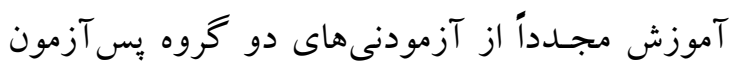
به عمل آمد و سرانجام دادههـاى حاصله با روشهاى آمارى مورد تجزيهوتحليل قرار كرفتند. ملاككهاى ورود به بُزوهش عبارت بودند از: داشتن تمايل براى مشاركت در يُزوه، مبتلا نبودن به اختلالات

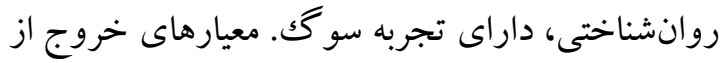

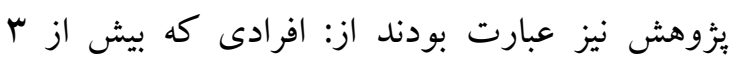

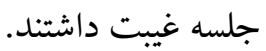

مختلف زندگى با همديخر ارتباط و هماهنكى داشته باشند (اكبرى، العه1). در يُزوهشهاى مختلف اثربخشى معنا درمانى بر بهزيستى روانشناختى و تابآورى را در جامعههاى

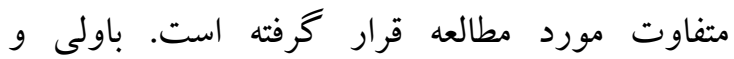

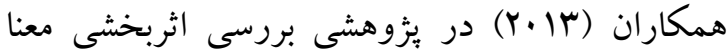

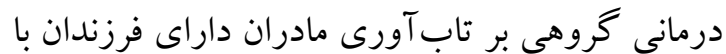

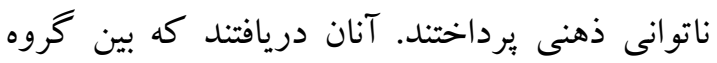
آزمايشى و كنترل تفاوت معنادارى وجود داشته و جلسات معنا درمانى منجر به افزايش تاب آورى مادران داراى فرزندان ناتوانى يادگيرى شده است. امانى و

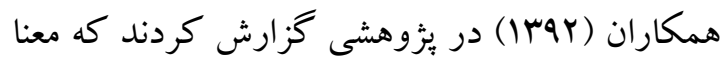
درمانى به شيوه گروهى بر تاب آورى و احساس تنهايى دانشجويان دختر داراى نشانگًان ضربه عشق در گروه

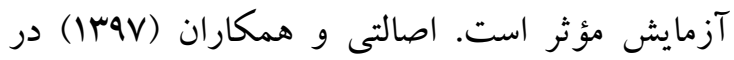
يثزوهشى نشان دادند كه معنا درمانى فر انكل بر كاهش

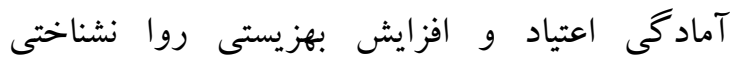
دانشجويان دختر مبتلا به افسردگى تأثير دارد. تقوايىنيا

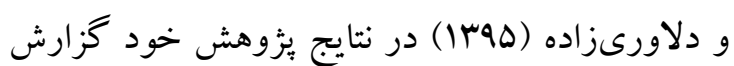
كردند كه معنادرمانى گروهى بر افزايش بهزيستى روانشناختى زنان بازنشسته سالمند تأثير دارد. يرولكس، هلمز و بوهلر' (Y..V.

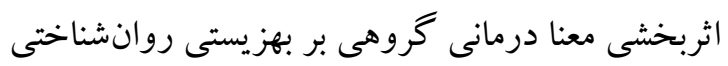
برداختند. آنها به اين نتيجه رسيدندكه معنا درمانى

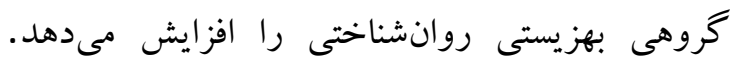

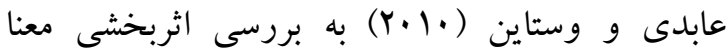
درمانى كروهى بر بهزيستى ذهنى و سلامت روان برداخته و نشان دادند كه معنا درمانى شاخص هاى برى بهزيستى روانشناختى را ارتقا مىدهد. با توجه به مطالب بالا، از ضرورت انجام اين يزوهش

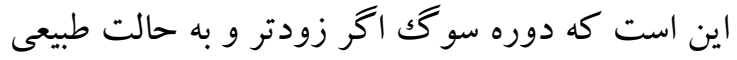

\footnotetext{
${ }^{1}$. Proulx, Helms \& Buehler
} 
يرسشنامه تاب آورى: اين :برسشنامه را كانر و

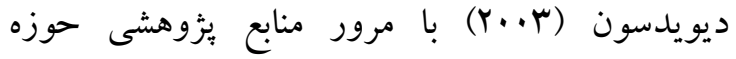
مقياس بهزيستى روانشناختى ريف: ريف و و كيز تاب آورى تهيه كردند. تهيه كنند گان اين مقياس بر اين

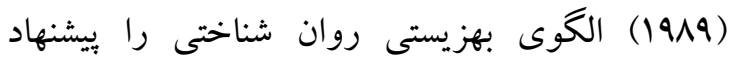
عقيداند كه اين برسشنامه به خوبى قادر به تفكيك نمودند و يكك مفهوم جند مؤلفهاى است بر اساس ته

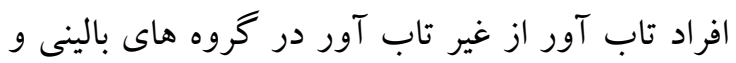
الكوى ريف (1919) از شش عامل يذّيرش، خود غير بالينى بوده و مىتواند در موقعيتهاى يزوهشى و

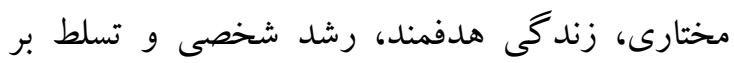

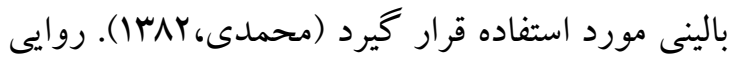
(به روش تحليل عاملى) و وِايايى (به روش آلفاى

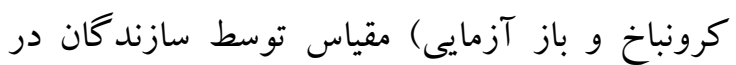
كروههاى مختلف (عادى و خطر) احراز گرديده است. جايايى و روايى فرم فارسى مقياس تاب آورى نيز درمطالعات مقدماتى نمونه هاى بهنجار و بيمار مورد بررسى و تائيد قرار گرفته است (بشارت، ومبا نقل از

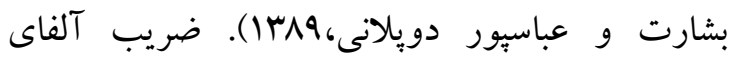
كرونباخ مقياس برابر سو/ • حاصل شد كه كاملاً منطبق با بايايى گزارش شده توسط سازند گان مقياس بود. روايى اين سازه نيز در ايران توسط بشارت (9 بها)

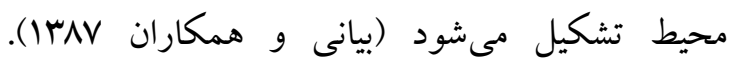
همبستخى معنادار بين مقياسهاى بهزيستى روانشناختى لهنى ريف و يرسشنامه هاى رضايت از شادكامى و عزت نفس حاكى از اعتبار اين آزمون است. همجِنين بيانى و

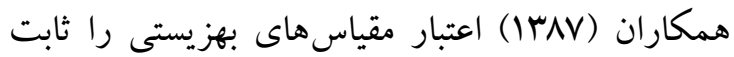
كردند. ريف طى يثزوهشى بايايى حاصل از روش باز

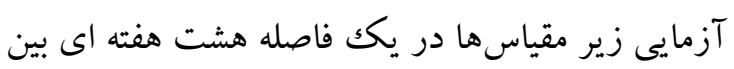

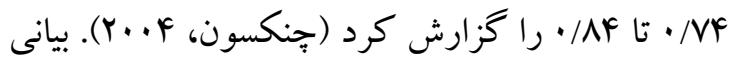
و همكاران (INAV) به منظور هنجاريابى مقياس هاى بهزيستى روانشناختى در ايران به ضريب بايايى Ar/ • دست يافت؛ كه از نظر آمارى معنىدار بود. تائيد شده است.

جدول ا محتواى جلسات آموزش معنادرمانى

جلسات

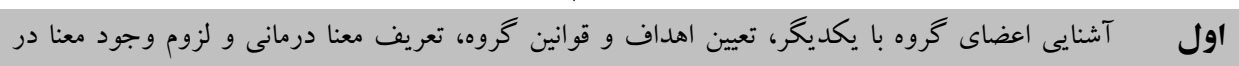
زندى دوم اهى در خصوص باورها در بذيرش خويشتن و شناخت ويز گيهاى خويش و همجنين توجه به آزادى معنوى به عنوان يكى از ابعاد هستى انسان سوم مرور تكليف جلسه قبل و دادن بازخورد، آكاهى از مسئوليت يذيرى و نقش آن در به دست آوردن موفقيت

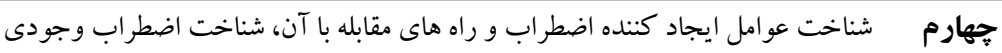

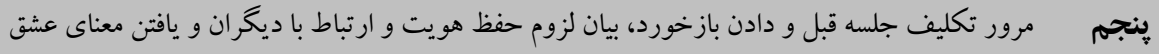

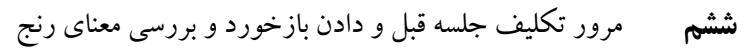

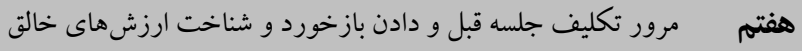

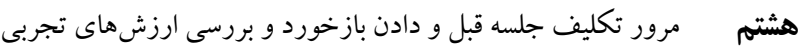

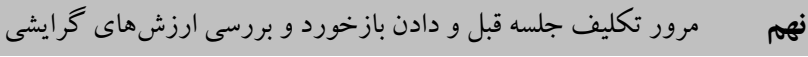
دهم خلاصه و جمعبندى جلسات و اجراى بس آزمون

يافتهاى توصيفى نشان داد كه دامنه سن افراد نمونه

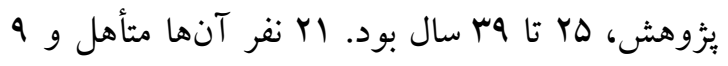


ميـانگين و انحراف استاندارد نمرات متغيرها در

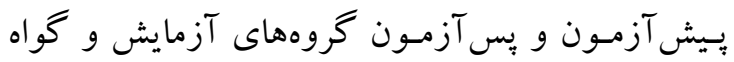

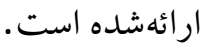

نفر آنها مجرد بودند. ميزان تحصيلات افراد

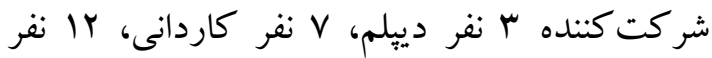
كارشناسى و 1 نفر كارشناسى ارشد بود. در جـدول r

جدول ץ ميانكَين و انحر اف استاندارد براى كروه آزمايش و كواه

\begin{tabular}{|c|c|c|c|c|c|c|c|c|}
\hline \multicolumn{4}{|c|}{ كواه } & \multicolumn{4}{|c|}{ آزمايش } & كروه \\
\hline \multicolumn{2}{|c|}{ يَس آزمون } & \multicolumn{2}{|c|}{ ييش آزمون } & \multicolumn{2}{|c|}{ پֶ آزمون } & \multicolumn{2}{|c|}{ بيش آزمون } & موقعيت \\
\hline أنحراف & ميانكين & انتحراف & ميانغين & انحتراف & ميانكين & انتحراف & ميانكين & متغيرها \\
\hline$r / v \Delta$ & $M F / \wedge G$ & $F / 4 q$ & rY/Tr & $9 / 1 V$ & $r \cdot r$. & $r / q 1$ & $\mathrm{r} / \mathrm{A}$. & تاب آورى \\
\hline T/AF & $\Delta 9 / M$ & $r / 19$ & $\Delta \Delta / V \mu$ & $r / r \mu$ & $95 / .9$ & $r / \cdot 1$ & $\Delta \Delta / 99$ & روانشناختى بهزي \\
\hline
\end{tabular}

جدول ب نتايج اطلاعات مربوط به شاخص هاى اعتبارى آزمون كواريانس را نشان مى دهد.

جدول r اطلاعات مربوط به شاخصهاى اعتبارى آزمون كواريانس

\begin{tabular}{|c|c|c|c|c|c|c|}
\hline مجذور & معنادارى سطح & خطاى درجه & فرضيه درجه & فراوانى & مقدار & نام آزمون \\
\hline$\cdot / 491$ & $\%$ & $r \mathrm{~V} / \ldots$ & $r / \ldots$ & $\mid r / r A r$ & $\cdot / 491$ & اثر بيلايى \\
\hline$\cdot / 491$ & $\cdot / \cdots$ & $r \mathrm{r} / \cdots$ & $r / \cdots$ & Ir/rAr & $\cdot / \Delta \cdot r$ & لامبدا ويلكز \\
\hline$\cdot / 491$ & $\cdot \ldots$ & $r \mathrm{r} / \ldots$ & $r / \ldots$ & Ir/TAY &.$/ 991$ & اثر هتلينك \\
\hline$\cdot / 491$ & $\%$ & $r v / \ldots$ & $r / \ldots$ & $\mid r / r \Delta r$ &.$/ 991$ & بزركتترين ريشه - \\
\hline
\end{tabular}

واريانس يا تفاوت بين دو گروه مربوط به تأثيرات آموزش معنا درمانى است.
نتايج جدول r نشان مىدهد كه تفاوت بين Y گروه به مقدار •ه درصد معنادار است، يعنى •ه درصد

\begin{tabular}{|c|c|c|c|c|c|c|}
\hline ضرايب & معنادارى سطح & فراوانى & مجذيانكين & آزدى درجه & مجذورات & منابع تغييرات \\
\hline$\cdot / 94 r$ & $\cdot \cdots$ & $1919 / \% \cdot 0$ & FrYGY/DTr & 1 & FrYGY/DTr & اثر هميراش \\
\hline \multirow[t]{3}{*}{ D/rYq } & $\cdot \cdots \wedge$ & $N / 109$ & (TוT/TMT & 1 & rir/rrr & كروه (آزمايش / كواه) \\
\hline & & & rQ/IFA & rı & NTr/ITr & خطا \\
\hline & & & & $r$. & Rrr.N/N. & كل \\
\hline
\end{tabular}


درمانى بر تابآورى زنان داراى تجربه سو گك تأثير

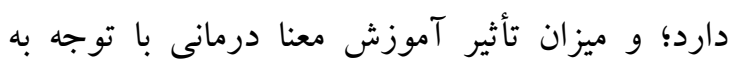

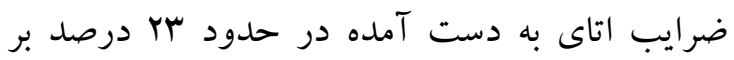

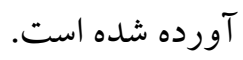

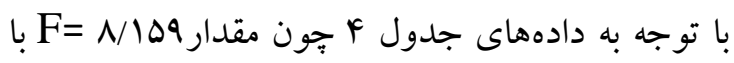

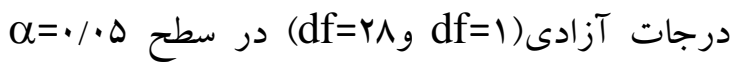
معنادار است، بنابر اين فرض صفر رد و فرض تحقيق با

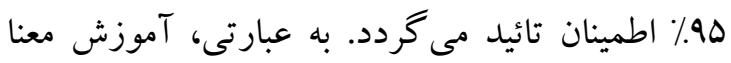

جدوله نتايج تحليل كواريانس متغير بهزيستى روانشناختى

\begin{tabular}{|c|c|c|c|c|c|c|}
\hline ضرايب & معنادارى سطح & فراوانى & مجذوراتكين & درجه آزدى & مجذورات & منابع تغييرات \\
\hline •/१९८ & $\cdot \cdots$ & $114 \cdot \Delta / 19$ & $1 \cdot \Delta \wedge \Delta \cdot / \Lambda \cdot$ & 1 & $1 \cdot \Delta \wedge \Delta \cdot / \Lambda \cdot$. & اثر هميراش \\
\hline \multirow[t]{3}{*}{$\cdot / 4 \Delta 1$} & $\cdot \cdots$ & $r Y / Q \wedge 9$ & (T) & 1 & TIT/MTr & كروه (آزمايش / كواه) \\
\hline & & & $9 / Y \wedge 1$ & r^ & $r \Delta Q / \Lambda 9 V$ & خطا \\
\hline & & & & $r$. & $1 . q r r F / \ldots$ & كل \\
\hline
\end{tabular}

داراى تجربه سو كُ يافت نشد. نتايج ئوهش حاضر از

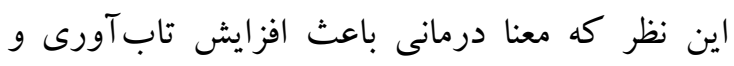

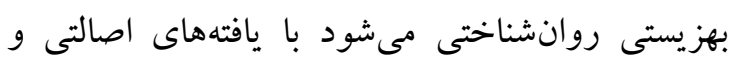

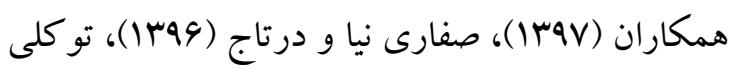

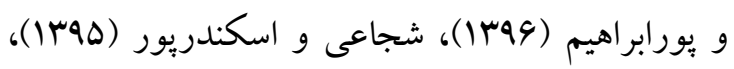

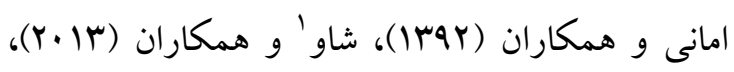

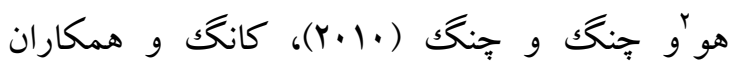
(Y..q)

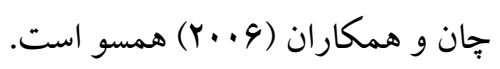

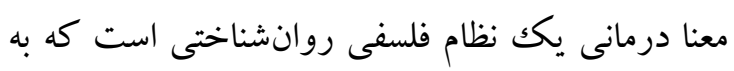

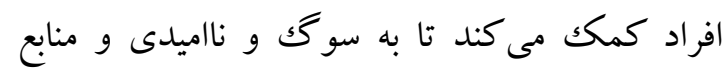
ازدسترفته تمر كز نكنند بلكه در جستجوى معنا باشند و برنامهريزى بهترى براى وضعيت موجود داشته باشند

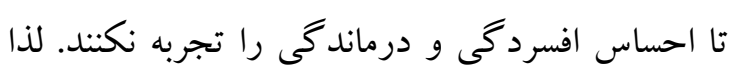

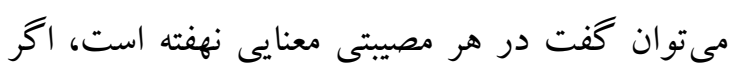
بيذيريم كه جهانى كه ما در آن زندگى مئى كنيم جهان

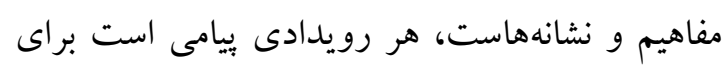

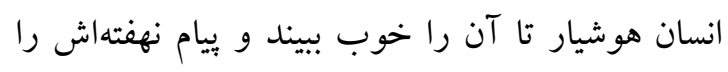
دركك كند. اخر افراد ميدان ديد خود را وسعت دهند

\footnotetext{
'. Shao

2. Ho., Cheung \& Cheung
}

با توجه به دادههاى جدول ه جون مقدار F=rr/A19 با

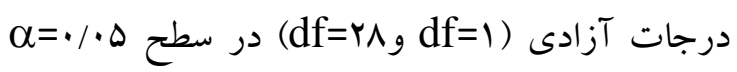
معنادار است، بنابراين فرض صفر رد و فرض تحقيق با

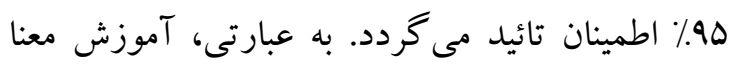
درمانى بر بهزيستى روانشناختى زنان داراى تجربه

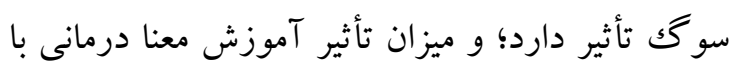

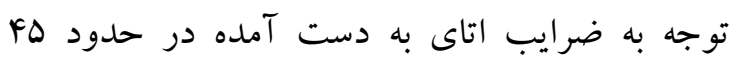
درصد بر آورده شده است.

يُزوهش حاضر با هدف اثربخشى آموزش معنا درمانى

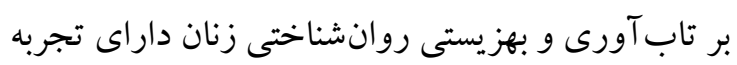

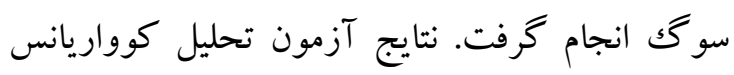

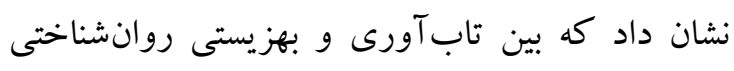

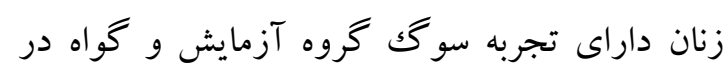

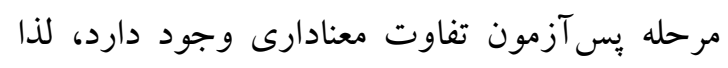

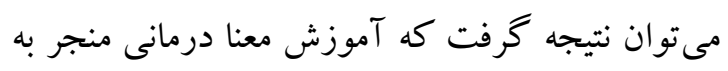

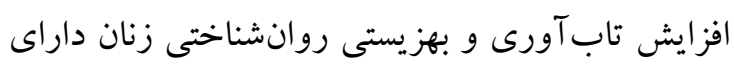

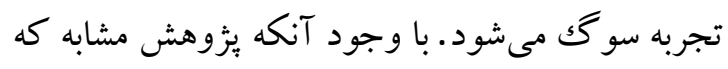
به طور دقيق و به همين روش به بررسى اثر معنا درمانى بر افزايش تاب آورى و بهزيستى روانشناختى در زنان 
يذيرى به معناى اعتقاد به اين است كه امن فعلاً همين

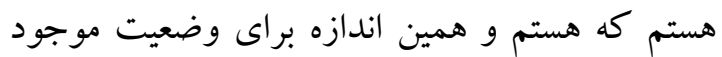

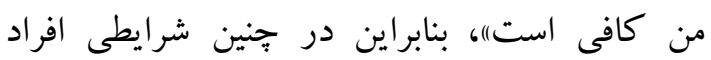

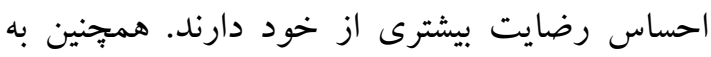

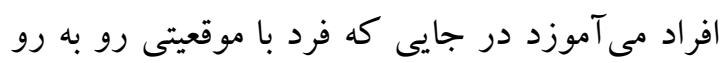
مىشود كه به هيج وجه نمىتواند آن را تغيير دهد واكنشهاى مناسب با آن موقعيت را از خود بروز

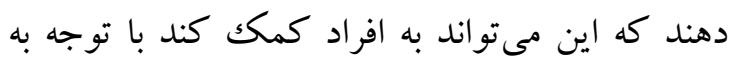

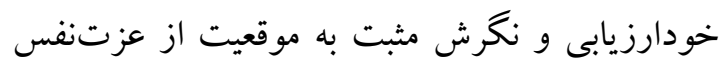
خود حمايت و دفاع نمايند كه اين امر خود ارتقاى بهزيستى روانشناختى را به دنبال دارد. در خصوص

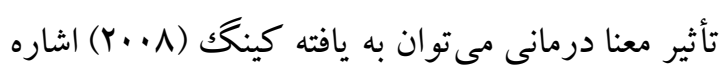
كرد كه بيان مى كند تفكر وجودى يعنى انديشيدن به معان

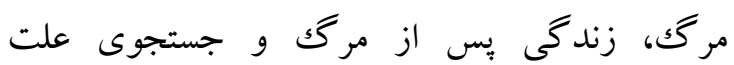

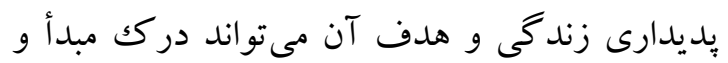
مقصد حيات بشرى و جهان خلقت را براى افراد آسان كند. جِنين دركى افراد را به سوى انتخاب اهداف والا سوق داده و هدف زندكى آنها را سازمان مىدهد. بنابر اين با توجه به مطالب بالا معنا درمانى مىتواند از

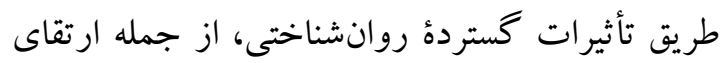

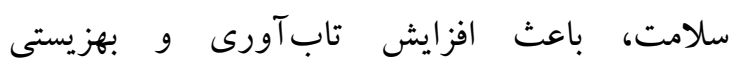
روانشناختى زنان داراى تجربه سو گك شود.

\section{نتيجه كيرى}

در كل نتايج اين يزوهش نشيرى نشان داد كه آموزش معنا

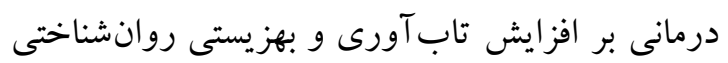
مؤثر است. اين روش مىتواند به صورت فردى و و

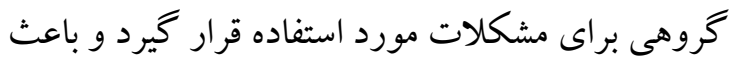
ارتقاء سلامت روانى و واكنشهاى مؤثر و ساز گارانه افراد در برابر رويدادهاى آسيبزاى زندگى شود كه در مطالعات آينده هم مىتوان آن را مشاهده كرد. يزوهش حاضر داراى محدوديتهايى از جمله، مرحله
تا معنا و ارزش نهفته شده در آن مصيبت را ببيند آنگاه قادر خو اهند بود شجاعانه آن را بيذيرند و با بآن آن مبارزه كنند و وقتى به پيذيرش برسند مىتواند به وظايف و مسئوليتهاى خود رسيدگى كنند. انسان

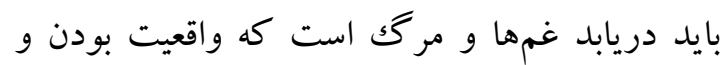
زندگى را توجيه مى كند و وجود انسان ر ا شكوفا

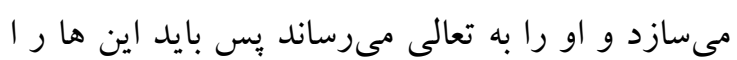

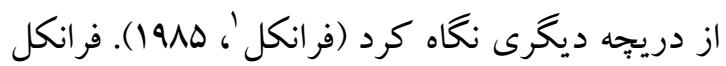
اطمينان مى دهد كه ناميدى نوعى موفقيت محسوب مى شود. اين موضوع علامت عمق فكرى فرد است و به هيج وجه به سطحى بودن وى مربوط نمى شود،

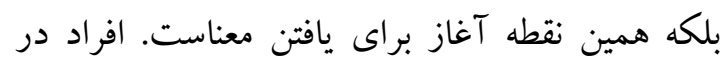

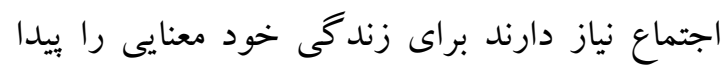

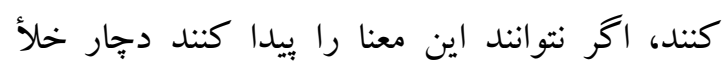

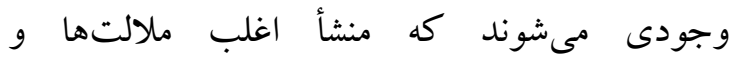
بى حوصلحى هاست كه روز گار ما به شدت از اين خلأ رنج مى كشد. مى توان كفت تاب آورى (ايكك فر آيند، توانايى يا بيامد ساز كارى موفقيت آميز با شرايط

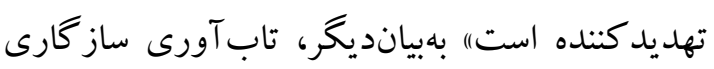
مثبت در واكنش به شرايط ناكوار است. البته تابآورى تنها بِيدارى در برابر آسيبها يا شرايط

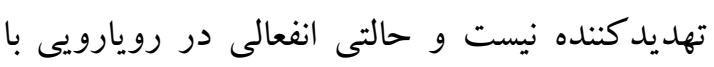
شرايط خطرناك نيست؛ بلكه شركت فعال و سازنده در محيطى بيرامونى خود است افراد تابآورى قادر

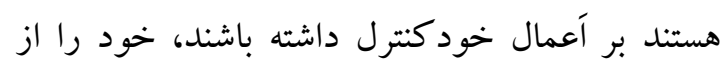

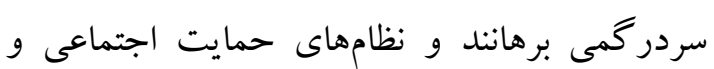
روابط خانوادگى گستردهترى فراهم كنند تا به آنان براى ساز گارى بهتر كمك كنند.

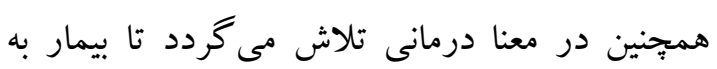
خودش رجوع كند. معنا درمانى به افزايش خودشناسى و خويشتن بذيرى مىانجامد. از آنجايى كه خويشتن -

\footnotetext{
1. Frankl
} 
intervention. Thesis submitted in the fulfillment of the requirements of the degree doctor in industrial psychology. University Of Johannesburg.

Chan, H. Y., Chan, L. W., Lee, M., Phil, M., Chan, H. Y., \& Lau, J. (2006). Group debriefing for people with chronic diseases during the sars pandemic: Strength- focused and meaningoriented approach for resilience and transformation. Community Mental Health Journal, 42, 53-63.

Dargahi P. (2016). The Effectiveness of Meaning Therapy on Psychological Well-Being and Quality of Life in Physically-Disabled Girls. M.Sc. thesis, Azad University, Karaj Branch.

December, D. (2013).Individual and Environmental Comelates of Anxiety in Parentally Bereaved Children. A Thesis Submitted in Partial Fulfillment of the Requirements for the Degree of Bachelor of Arts with Honors in Psychology from the University of Michigan.

Downing, T., Folke, C., \& Nelson, D. (2010). Resilience and vulnerability: Complementary or conflicting concepts? Ecology and Society, 15 (3), 11.

Frankl VE. (1985). Man's Search for Meaning. New York: Simon and Schuster.

Ho, M. Y., Cheung, F. M., \& Cheung, S. F. (2010). The role of meaning in life and optimism in promoting well-being. Personalityand Individual Differences, 48, 658-663.

Hutchinson GT, Chapman BP. (2005). Logotherapyenhanced REBT: An integration of discovery andreason. Joumal of Contemp Psychother. 35 (2): 145-55.

Kang, K. A., Im, J. I., Kim, H. S., kim, S. J., Song, M. K., \& Sim, S. (2009). The effect of logo therapy on the suffering, finding meaning, and spiritual well-being of terminal cancer. Korean Acad Child Health Nurs, 15, 136144.

Khorakchi P. (2018). Teaching Meaning Therapy on Psychological Resilience and Well-being of Women in Tehran. M.Sc. thesis at Roudehen Azad University.

Mohammadpour Yazdi AR. (2006). Victor Emile Frankel, Founder of Therapeutic Meaning (An Overview of Existential Psychology

$$
\begin{aligned}
& \text { بيخيرى يس از درمان صورت نخرفت. بيشنهاد مىشود } \\
& \text { در مطالعات بعدى، آموزش معنا درمانى در شهرهاى } \\
& \text { مختلف به خاطر تفاوتهاى فرهنكى مورد بررسى قرار } \\
& \text { كيرد. همجنين به عنوان يكك شيوه كار آمد در جهت } \\
& \text { كاهش اثرات سو گك در افراد مورد استفاده قرار گيرد. }
\end{aligned}
$$

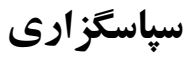

با سياس از تمامى عزيزان مورد يُوهش كه با صبر و

شكيبايى ما را در انجام اين يزوهش يارى رساندند؛ و

همجِنين كسانى كه در انجام اين يُوهش همكارى

داشتهاند.

\section{References}

Ahar Asheghi R. (2015). The Effectiveness of Reality Therapy Training on Psychological Wellbeing and Resilience of Ahar Seismic Women. M.Sc. thesis at Abhar Azad University.

Akbari M. (2012). The Relationship between Meaning of Life and Religion with Resilience in Veterans of Qazvin. M.Sc. thesis at Shahid Beheshti University.

Amani A, Yousefi N, Ahmadi S. (2013). Effectiveness Group-based therapies on resilience and feelings of loneliness in female students with PTSD. Counseling Research, Volume 13, Number 49, pp. 101101.

Asalati P, Arab A, Mehdi Nejad V. (2018). The Effectiveness of Frankel Symptom Therapy on Reducing Addiction Readiness and Increasing the Psychological Well-Being of Depressed Female Students. Iranian Journal of Health Education and Health Promotion, Volume 7, Number 1;pp. 84-92.

Bavali, F., Faramarzi, S., Manshaie, G., Khaledian, M. (2013). Effectiveness of Group Logo Therapy on Resiliency of the Mothers with intellectual disability Children. World of Sciences Joumal, Vol. 1(7), 115-123.

Burger, D. H. (2007). The applicability of logo therapy as an organization development 
and Psychotherapy), Tehran: Dangier Publishing, FirstEdition.

Nel, L. (2011). The Psychofertological Experiences of Master s Degree Students in Professional Psychology Programs: An Interpretative Phenomenological Analysis. Thesis in fulfilment of the requirements for the degree. Department Of Psychology Faculty of the Humanities: University of the Free State Bloemfontein. 48- 84.

Proulx, C. M, Helms, H. M., Buehler, C. (2007) marital quality and personal well-being. Ametaanalysis. Joumal of Marriage and Family, (69):576-593.

Qaderi M. (2012). The Effectiveness of Reality Therapy Training on Psychological WellBeing of Students in Tehran. M.Sc. thesis at Roudehen Azad University.

Rosner R., Pfoh, G., \& Kotoucova, M. (2011).Treatment of complicated grief. European Joumal of Psycho traumatology, 2, 1-10.

Ryff, C. D., \& Singer, B. H. (2008). Know thyself and become what you are: A eudaimonic approach to psychological well-being. Journal of Happiness Studies, 9(1).

Saffarinia M, Dartaj A. (2016), The Effectiveness of Group Meaning Therapy on Life Expectancy and Psychosocial Well-being of Elderly Women Residing in Dubai Sanatoriums. Elderly Joumal, Volume 12, Number 4, pp. 484-493.

Shao, J., Shen, J., Zhang, K., \& Lin, T. (2013). Meaning in life and well-being of older stroke survivors in Chinese communities: Mediating effects of mastery and selfesteem. Health, 5(4), 743-748.

Shojaei A, Eskandarpour B. (2016). The Effectiveness of Frankel Group Meaning Therapy on the Psychological Well-Being and Happiness of the Headless and Bad Headed Students. Journal of School Psychology, Volume 5, Number 2, pp. 7191.

Stamp, E; Crust, L.; Swann, C.; Perry, J.; Clough, P.; Marchant, D (2015). Relationship between mental toughness and psychological wellbeing in undergraduate students. Personality and Individual Differences 75. 170-174.
Taghvainia A, Delavarizadeh S. (2016) The Effectiveness of Group Logotherapy on Increasing the Psychological Well-Being of Elderly Retired Women. Joumal of Aging Psychology, Volume 2, Number 2, pp. 115124.

Tavakoli B, Purebrahim T. (2017). The effectiveness of group meaning therapy on obsessive beliefs and resilience of women. Joumal of Disability Studies, Volume 8, Number 1, pp. 1-7.

Vardon PJ. (2009). A three-dimensional numerical investigation of the thermo-hydromechanical behavior of a large-scale prototype repository. Cardiff University.P:18.

Yamaguchi, S. Kawata, Y. Shibata, N. \& Hirosawa, M. (2017). Direct and Indirect Effect of Hardiness on Mental Health among Japanese University Athletes. In International Conference on Applied Human Factors and Ergonomics (pp. 148154). Springer, Cham. 